\title{
Analisis determinan impor beras di Indonesia
}

\author{
Muhammad Rizky Mulya*; Haryadi; Rahma Nurjanah
}

Prodi Ekonomi Pembangunan Fak. Ekonomi dan Bisnis Universitas Jambi

*E-mail korespodensi: Rizkymulya01@gmail.com

\begin{abstract}
This study aims to determine and analyze the development of a gross domestic product, population, rupiah exchange rate, inflation, and rice imports. In addition, to choose and investigate the effect of gross domestic product, people, rupiah exchange rate, inflation, and rice imports. The method used to analyze this research is descriptive quantitative. This study uses multiple linear regression analysis based on Ordinary Least Square $(O L S)$. Based on the results of this study, the development of rice imports fluctuates every year. It tends to increase rice imports, gross domestic product fluctuates and tends to grow, the population increases every year, the rupiah exchange rate fluctuates, and inflation fluctuates every year and tends to decrease. The results of multiple linear regression show that the variables of gross domestic product, population, and exchange rate significantly affect rice imports in Indonesia. In contrast, the inflation variable is not substantial on rice imports in Indonesia.
\end{abstract}

\section{Keywords: Import rice, GDP,Total population, Exchange rate, Inflation.}

\begin{abstract}
Abstrak
Penelitian ini bertujuan untuk mengetahui dan menganalisis perkembangan Produk domestik bruto, jumlah penduduk, nilai tukar rupiah, inflasi dan impor beras. Selain itu juga untuk mengetahui dan menganalisis pengaruh Produk domestik bruto, jumlah penduduk, nilai tukar rupiah, inflasi dan impor beras. Metode yang digunakan untuk menganalisis penelitian ini adalah deskriptif kuantitatif. Penelitian ini menggunakan alat analisis regresi linear berganda yang berbasis Ordinary Least Square (OLS). Berdasarkan hasil penelitian ini bahwa perkembangan impor beras mengalami fluktuasi setiap tahunnya dan cenderung terjadi peningkatan terhadap impor beras, produk domestik bruto berfluktuasi dan cenderung meningkat, jumlah penduduk mengalami peningkatan setiap tahunnya, nilai tukar rupiah fluktuasi serta untuk inflasi mengalami fluktuasi setiap tahunnya dan cenderung terjadi penurunan Adapun hasil dari regresi linear berganda menunjukkan bahwa variabel produk domestik bruto, jumlah penduduk, nilai tukar berpengaruh signifikan terhadap impor beras di Indonesia, sedangkan variabel inflasi tidak signifikan terhadap impor beras di Indonesia
\end{abstract}

Kata kunci: Impor Beras, PDB, Jumlah Penduduk, Nilai Tukar dan Inflasi

\section{PENDAHULUAN}

Perdagangan internasional diartikan sebagai suatu aktivitas yang dilakukan oleh penduduk negara satu dengan penduduk negara lain atas dasar kesepakatan bersama. Adapun tujuan utama dari aktivitas ini adalah keuntungan yang diperoleh masingmasing negara yang akan dibandingkan dengan negara lain, keuntungan ini dinamakan keuntungan absolut atau mutlak.

Suatu negara mau berdagangan dengan negara lain karena negara tersebut ingin mendapatkan manfaat dari perdagangan. Seperti halnya dengan individu, manusia itu 
sendiri sangat relatif terbatas. Karena sifat tersebut, saat ini tidak ada lagi negara yang dapat menghasilkan kebutuhannya sendiri. Keyakinan bahwa perdagangan luar negeri mampu memberikan manfaat baik terhadap negara maupun penduduk suatu negara telah mendorong timbulnya perdagangan internasional (Haryadi, 2012).

Transaksi impor adalah perdagangan dengan cara memasukan barang dari luar negri kedalam daerah pabean Indonesia dengan memenuhi ketentuan peraturan perundang-undagan yang berlaku (Tandjung, 2011). Indonesia sebagai negara yang sedang berkembang menghadapi masalah pertanian, khususnya masalah pangan. Tahun 2015 Indonesia merupakan negara peringkat ketiga sebagai produsen padi terbesar setelah China dan India. Tetapi beberapa tahun terakhir Indonesia perlu mengimpor sekitar 3 juta ton beras setiap tahunnya, terutama dari Thailand dan Vietnam, untuk mengamankan cadangan beras negara.

Berdasarkan data Badan Pusat Data Statistik 2018 negara Vietnam, Thailand, Tiongkok, Pakistan, Amerika Serikat, Taiwan dan India adalah negara tujuan pengimpor beras pada tahun 2017. Volume impor beras Indonesia pada tahun 2014 volum impor beras yaitu 844.164 Ton. Pada tahun 2015 naik menjadi sebesar 861.601 Ton, tiga tahun terakhir volume impor cenderung mengalami fluktuasi. Pada tahun 2016 volume impor berada di angka 1.073.720 Ton pada tahun 2017 mengalami penurunan menjadi 311.520 Ton pada tahun 2018 lalu volume impor naik menjadi 2.253 .824 ton.

Apabila penentuan volume impor beras tidak terkontrol, dampak negatif yang dapat dirasakan adalah surplus beras yang berlebihan di pasaran sehingga menyebabkan harga turun dan membuat masyarakat hidup konsumtif juga dapat menimbulkan inflasi. Sebaliknya apabila volume impor beras kurang dapat menutupi kesediaan beras dipasaran maka menyebabkan harga beras tinggi karena stok menipis. Dampak negatif apabila volume impor beras tidak terkontrol adalah pemborosan devisa negara yang difokuskan kepada impor beras padahal devisa negara dapat dialokasikan ke sektor lain yang membutuhkan impor.

Ada beberapa faktor yang mempengaruhi dari impor beras Indonesia ini diantaranya adalah PDB, jumlah penduduk, nilai tukar dan inflasi. Faktor lain yang cukup berpengaruh terhadap impor beras adalah Produk Domestik Bruto. Perubahan pada tingkat pendapatan suatu negara akan membawa perubahan pada tingkat impor. Impor dapat terjadi dikarenakan pendapatan dalam negeri meningkat sehingga kemampuan penduduk untuk membeli barang-barang imporpun meningkat. PDB merupakan statistika perkonomian yang dianggap sebagai ukuran tunggal terbaik mengenai kesejahtreraan masyarakat karena mengukur total pendapatan semua orang dalam perekonomian dan total pembelanjaan negara barang dan jasa hasil perekonomian (Armaini, 2016).

Selain PDB salah satu penyebab utamanya impor beras di Indonesia adalah jumlah penduduk yang sangat besar. Tingginya impor tingkat ketergantungan pada impor beras ini tidak lepas dari pertambahan jumlah penduduk dan faktor-faktor lain yang mempengaruhi impor beras Indonesia, impor ini dilakukan agar kebutuhan beras dalam negeri dapat terpenuhi.

Apabila kurs valuta asing mengalami kenaikan terhadap mata uang dalam negeri, maka hal ini dapat mengakibatkan terjadinya penurunan impor dan begitupun apabila kurs valuta asing mengalami penurunan terhadap mata uang dalam negeri maka hal ini dapat meningkatkan impor (Selien, 2012)

Selain faktor-faktor diatas, salah satu faktor yang mempengaruhi impor beras di Indonesia adalah inflasi. Inflasi menyebabkan harga barang impor menjadi lebih murah dari pada barang yang dihasilkan dalam negeri, maka pada umumnya inflasi akan menyebabkan impor beras berkembang lebih cepat. Inflasi adalah gejala ekonomi yang menunjukkan naiknya tingkat harga secara umum yang berkesinambungan. Syarat inflasi yaitu terjadi kenaikan harga-harga secara umum dan terus-menerus. Jika hanya 
satu atau dua jenis barang saja yang naik, itu bukan merupakan inflasi (Hasyim, 2016).

\section{METODE}

Jenis data yang penulis gunakan dalam penelitian ini berupa data sekunder. Menurut Widarjono (2017), data runtut waktu merupakan sekumpulan observasi dalam rentang waktu tertentu. Data ini dikumpulkan dalam interval waktu secara kontinu. Dalam penelitian ini digunakan data time series tahun 1998 - 2018 yang diperoleh dari berbagai sumber. Alat analisis yang digunakan dalam penelitian ini adalah sebagai berikut:

Untuk menjawab tujuan pertama digunakan rumus :

$\mathrm{P}_{\mathrm{M}}=\frac{\mathrm{M}_{\mathrm{t}-M-t-1}}{M_{t-1}}$

Dimana:

$\mathrm{P}_{\mathrm{M}} \quad$ : Perkembangan impor beras

Mt : Impor beras tahun $\mathrm{t}$

$\mathrm{M}_{\mathrm{t}-1} \quad$ : Impor beras tahun $\mathrm{t}$ sebelumnya

Untuk menganalisis pengaruh PDB, jumlah penduduk, nilai tukar dan inflasi terhadap impor beras di Indonesia dengan menggunakan analisis regresi linier berganda. Berikut model estimasi cadangan devisa Indonesia yang digunakan dalam penelitian ini:

$$
Y=\beta_{0}+\beta_{1} P_{1 t}+\beta_{2} J_{-} P_{e n}+\beta_{3} N_{3 t}+\beta_{4} I N F_{4 t}+\varepsilon_{t}
$$

Dimana:

Y $\quad=$ Impor Beras (ton)

$\mathrm{B}_{1,2,3}=$ Koefisien regresi

$\mathrm{PDB}_{1 \mathrm{t}}=$ Produk domestik bruto (milyar rupiah)

$\mathrm{J} \_P e n_{2 \mathrm{t}}=$ Jumlah penduduk (jiwa)

$\mathrm{NT}_{3 \mathrm{t}} \quad=$ Nilai tukar (dollar AS)

$\mathrm{INF}_{4}=$ Inflasi (persen)

$\mathrm{B}_{\mathrm{o}} \quad=$ Konstanta

$\varepsilon_{\mathrm{t}} \quad=$ Error term/standar eror

\section{Pengujian hipotesis}

\section{Uji signifikansi secara simultan (Uji F)}

Widarjono (2013) uji ini dilakukan untuk melihat apakah ada hubungan antara variabel independen secara bersama-sama terhadap variabel dependen. Untuk mengetahui apakah semua variabel independen berpengaruh secara serentak terhadap variabel dependen.

\section{Uji signifikansi secara parsial (Uji t)}

Tujuan uji-t untuk menganalisis hipotesis secara persial (individu) guna mengetahui seberapa besar signifikan atau tidak signifikannya pengaruh masing masing variabel.

\section{Koefisien determinan $\left(\mathbf{R}^{2}\right)$}

Pengukuran kecocokan model dilakukan dengan memperhatikan besarnya koefisien determinasi $\left(\mathrm{R}^{2}\right)$. Model dianggap baik atau cocok apabila $\mathrm{R}^{2}$ sekaligus 
menunjukkan besar pengaruh semua variabel independen terhadap variabel dependen, Nilai $\mathrm{R}^{2}$ akan meningkat dengan bertambahnya jumlah variabel bebas, derajat bebas akan semakin kecil, karena itu dipergunakan $\mathrm{R}^{2}$ Adjusted yang sudah dipertimbangkan derajat bebas, disamping itu dapat pula diketahui koefisien determinasi parsial $\left(\mathrm{R}^{2}\right)$ yang menunjukan seberapa besar kemampuan masing-masing variabel bebas mempengaruhi variabel terikat. (Gujarti, 2015)

\section{Uji asumsi klasik}

\section{Uji multikolineritas}

Multikoliniearitas merupakan hubungan linear antar variabel independen dalam regresi. Jika terjadi multikoliniearitas sangat tinggi, estimator OLS tetap memiliki sifat BLUE. Melihat multikolinearitas dapat menggunakan VIF. VIF atau toleransi adalah ukuran kolinearitas, dimana semakin besar VIF maka variabel independen semakin bermasalah (Gujarati, 2013).

\section{Uji heterokedastistas}

Heterokedastisitas adalah uji yang bertujuan menguji apakah dalam model regresi terjadi ketidaksamaan varians dalam suatu pengamatan terhadap pengamatan lainnya (Ghozali, 2011). Model regresi yang baik adalah model yang varians dari satu pengamatan ke pengamatan lain tetap.

\section{Uji autokorelasi}

Autokorelasi adalah uji yang bertujuan menguji apakah dalam model regresi linier ada korelasi antara kesalahan pengganggu pada periode $t$ dengan kesalahan pengganggu pada periode t-1 (Ghozali, 2011).

\section{Uji normalitas}

Dalam persamaan regresi, asumsi normalitas mensyaratkan nilai-nilai dari variabel $\mathrm{Y}$ berdistribusi normal pada tiap nilai dari X. Keadaan normal diketahui melalui sebaran regresi yang merata disetiap nilai. Uji normalitas bertujuan untuk menguji apakah dalam model regresi, variabel pengganggu dan residual memiliki distribusi normal (Ghozali, 2011).

\section{HASIL DAN PEMBAHASAN}

Perkembangan impor beras, produk domestik bruto, jumlah penduduk, nilai tukar, inflasi

Perkembangan impor beras Indonesia selama kurun waktu 1998-2018 mengalami fluktuasi dan cenderung meningkat, PDB selama kurun waktu 1998-2018 mengalami fluktuasi dan cenderung meningkat, jumlah penduduk selama kurun waktu 1998-2018 terus mengalami peningkatan, nilai tukar selama kurun waktu 1998-2018 cenderung mengalami apresiasi setiap tahunya sedangkan inflasi cenderung mengalami penurunan setiap tahunya.

\section{Pengaruh PDB, jumlah penduduk, nilai tukar dan inflasi terhadap impor beras Indonesia}

Faktor-faktor yang diduga berpengaruh terhadap impor beras di Indonesia adalah PDB, jumlah penduduk, nilai tukar dan inflasi. Berikut adalah hasil estimasi model 
regresi menggunakan metode OLS. Dari hasil estimasi data diatas dibentuk persamaan regresi berganda sebagai berikut:

IMPOR $=2.713713+5.225910$ PDB -0.000566 J_PEN + 26552117NT + 1.592408

INF

Tabel 1. Hasil regresi linier berganda

\begin{tabular}{lccc}
\hline \multirow{2}{*}{ Variable } & Coefficient & Uncentered & Centered \\
\cline { 2 - 4 } & Variance & VIF & VIF \\
\hline PDB & 5.225910 & 11.61468 & 7.075632 \\
J_PEN & 0.000566 & 1150.835 & 7.259177 \\
NT & 26552117 & 107.5122 & 4.010785 \\
INF & 1.592408 & 1.978295 & 1.391241 \\
C & 2.713713 & 980.3199 & NA \\
\hline
\end{tabular}

Sumber : Data diolah, 2021

\section{Pengujian hipotesis}

\section{Uji F}

Uji F-statistik dilakukan untuk melihat pengaruh variabel independen yaitu nilai tukar jumlah penduduk dan produk domestik bruto secara bersama-sama terhadap variabel dependen yaitu impor beras.

Berdasarkan hasil olahan data diperoleh, nilai F-statistik sebesar 6.910970 dengan probabilitas sebesar 0.000000 . karena nilai probabilitas lebih kecil dari tingkat keyakinan 5 persen, maka secara simultan variabel PDB, jumlah penduduk, nilai tukar berpengaruh signifikan terhadap variabel volume impor beras Indonesia sedangkan variable inflasi tidak berpengaruh signfikan terhadap impor beras di Indonesia.

\section{Uji t}

Pengujian ini dilakukan dengan membandingkan nilai probabilitas t-hitung $>\alpha$ (0.05) maka pengaruh variabel independen itu tidak signifikan, sehingga $\mathrm{H}_{0}$ diterima, yang artinya variabel independen tidak berpengaruh secara individual terhadap variabel dependen, sebaliknya jika probabilitas t-hitung < $\alpha(0.05)$ maka berpengaruh signifikan, sehingga $\mathrm{H}_{1}$ diterima, yang artinya variabel independen dapat mempengaruhi secara individual variabel dependennya. Hasil dari regresi linear berganda untuk menguji tstatistik dapat dilihat pada tabel berikut :

Tabel 2. Hasil linear berganda uji t-statistik

\begin{tabular}{lllll}
\hline Variable & Coefficient & Std. Error & t-Statistic & Prob. \\
\hline C & 21116884 & 5207169. & 4.055348 & 0.0009 \\
PDB & 0.000103 & 2.282705 & 4.509460 & 0.0004 \\
J_PEN & -0.066499 & 0.023800 & -2.794078 & 0.0130 \\
NT & -545.2311 & 162.9484 & -3.346036 & 0.0041 \\
INF & -5374.586 & 12618.19 & -0.425940 & 0.6758 \\
\hline \hline
\end{tabular}

Sumber: Data diolah, 2021

\section{Variabel produk domestik bruto}

Uji t-statistik untuk variabel PDB dapat dilihat pada tabel diatas menunjukkan nilai t-hitung sebesar $4.509460>1.725$ sehingga $\mathrm{H}_{0}$ ditolak. Maka PDB berpengaruh signifikan terhadap impor beras selama periode 1998-2018. Bila dilihat dari probabilitas nilai tukar yaitu sebesar $0.0004<0.05$, maka dapat disimpulkan bahwa PDB 
berpengaruh signifikan terhadap impor beras indonesia.

\section{Variabel jumlah penduduk}

Uji t-statistik untuk variabel jumlah penduduk dapat dilihat pada tabel diatas menunjukkan bahwa nilai t-hitung sebesar -2.794079> 1.725 sehingga $\mathrm{H}_{0}$ ditolak. Maka jumlah penduduk Indonesia berpengaruh signifikan terhadap impor beras selama periode 1998-2018. Bila dilihat dari probabilitas jumlah penduduk yaitu $0.0130<0.05$, maka dapat disimpulkan bahwa jumlah penduduk berpengaruh signifikan terhadap impor beras Indonesia.

\section{Variabel jumlah penduduk}

Uji t-statistik untuk variabel nilai tukar dapat dilihat pada tabel diatas menunjukkan bahwa nilai t-hitung sebesar $-3.346036<1.740$ sehingga $\mathrm{H}_{0}$ ditolak. Maka nilai tukar berpengaruh signifikan terhadap impor beras selama periode 1998-2018. Bila dilihat dari probabilitas nilai tukar yaitu $0.0041<0.05$, maka dapat disimpulkan bahwa nilai tukar berpengaruh signifikan terhadap impor beras Indonesia.

\section{Variabel inflasi}

Uji t-statistik untuk variabel inflasi dapat dilihat pada tabel diatas menunjukkan bahwa nilai t-hitung sebesar $-0.425940<1.740$ sehingga $\mathrm{H}_{0}$ ditolak. Bila dilihat dari probabilitas inflasi yaitu $0.6758<0.05$, maka dapat disimpulkan bahwa inflasi tidak berpengaruh signifikan terhadap impor beras Indonesia.

\section{Koefisien determinasi $\left(\mathbf{R}^{2}\right)$}

Koefisien Determinasi $\left(\mathrm{R}^{2}\right)$ menunjukkan seberapa besar variabel independent berpengaruh terhadap variabel dependen. Nilai $R^{2}$ berkisar antara $0-1$. Nilai $R^{2}$ makin mendekati 0 maka pengaruh semua variabel independent terhadap variabel dependent semakin kecil dan sebaliknya jika nilai $\mathrm{R}^{2}$ semakin mendekati 1 maka pengaruh variabel independen terhadap variabel dependent semakin besar. Dapat dilihat dari koefisien determinasi $\left(\mathrm{R}^{2}\right)$ sebesar 63.33 persen, sedangkan sisanya sebesar 36.67. persen dipengaruhi oleh variabel lain yang tidak termasuk dalam penelitian ini.

\section{Uji asumsi klasik}

\section{Uji multikolinearitas}

Pengujian multikolinearitas dilakukan untuk memastikan apakah model regresi menunjukkan adanya korelasi atau hubungan kuat antara dua varibel bebas atau lebih dalam sebuah model regresi berganda. Ada beberapa cara yang dapat dilakukan untuk mendeteksi adanya multikolinearitas salah satunya dengan melihat nilai variance inflation factor (VIF) pada model regresi, dengan ketentuan VIF $<10$ dideteksi model bebas multikolinearitas, VIF > 10 dideteksi model mengandung multikolinearitas.

Tabel 3. Uji multikolinearitas.

\begin{tabular}{llll}
\hline \hline Variable & $\begin{array}{l}\text { Coefficient } \\
\text { Variance }\end{array}$ & $\begin{array}{l}\text { Uncentered } \\
\text { VIF }\end{array}$ & $\begin{array}{l}\text { Centered } \\
\text { VIF }\end{array}$ \\
\hline PDB & 5.225910 & 11.61468 & 7.075632 \\
J_PEN & 0.000566 & 1150.835 & 7.259177 \\
NT & 26552117 & 107.5122 & 4.010785 \\
INF & 1.592408 & 1.978295 & 1.391241 \\
C & 2.713713 & 980.3199 & NA \\
\hline
\end{tabular}


Sumber : Data diolah, 2021

\section{Uji heterokedasitisitas}

Hasil uji heterokedastisitas, dapat dilihat bahwa nilai Prob. $F$ hitung yang dihasilkan (Prob. F $(3,34)$ ) sebesar 0,1243 lebih besar dari tingkat $a=5$ persen. Maka melalui uji Harvey dapat disimpulkan bahwa penelitian ini terbebas dari masalah heteroskedastisitas. Hasil perhitungan terlihat pada tabel sebagai berikut:

Tabel 4. Heterokedasticity test: Glejser

\begin{tabular}{llll}
\hline F-statistic & 0.509758 & Prob. F(4,16) & 0.7294 \\
Obs*R-squared & 2.373721 & Prob. Chi-Square(4) & 0.6674 \\
Scaled explained SS & 1.768271 & Prob. Chi-Square(4) & 0.7783 \\
\hline
\end{tabular}

Sumber : Data diolah, 2021

\section{Uji autokorelasi}

Berdasarkan uji serial correlation LM di dapat hasil uji autokorelasi, dapat dilihat nilai Prob. $F(2,14)$ sebesar 0,5688 lebih besar dari tingkat $a=5$ persen. Maka dapat disimpulkan bahwa penelitian ini terbebas dari masalah autokorelasi. Hasil perhitungan terlihat pada tabel sebagai berikut:

Tabel 5. Autokorelasi LM Test

Breusch-Godfrey Serial Correlation LM Test:

\begin{tabular}{llll} 
F-statistic & 0.587657 & Prob. F(2,14) & 0.5688 \\
Obs*R-squared & 1.626432 & Prob. Chi-Square(2) & 0.4434 \\
\hline
\end{tabular}

Sumber : Data diolah, 2021

\section{Uji normalitas}

Berdasarkan uji normalitas diketahui bahwa nilai Prob. Jarque-bera hitung sebesar 3,811389 lebih besar dari tingkat $a=5$ persen. Sehingga dapat disimpulkan bahwa residual terdistribusi normal yang artinya asumsi klasik tentang kenormalan telah dipenuhi. Hasil dari uji normalitas dapat dilihat pada gambar :

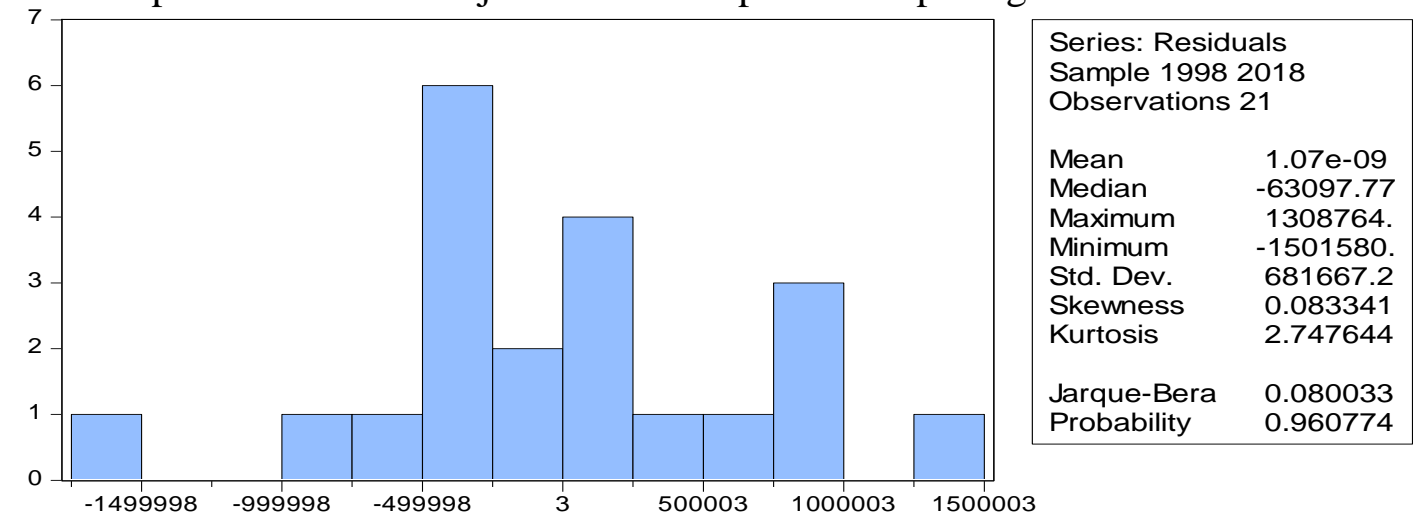

Gambar 1. Uji normalitas

\section{Imterpretasi hasil regresi}

Nilai konstanta (c) dari hasil estimasi diperoleh sebesar 21116.884 apabila PDB, jumlah penduduk, nilai tukar dan inflasi tidak mengalami perubahan atau tetap maka impor beras di Indonesia selama periode 1998-2018 diperkirakan mengalami peningkatan sebesar 21116.884. Variabel PDB memiliki hubungan positif terhadap impor beras di Indonesia dengan nilai koefisien sebesar 0.000103 mengartikan bahwa jika PDB mengalami peningkatan 1 milyar maka impor beras di Indonesia akan mengalami peningkatan sebesar 0.000103 ton. 
Variabel jumlah penduduk memiliki hubungan negatif terhadap impor beras di Indonesia dengan koefisien -0.066499 mengartikan jika PDB, jumlah penduduk, nilai tukar dan inflasi tetap maka setiap terjadi kenaikan jumlah penduduk sebesar satu jiwa maka volume impor beras di Indonesia akan menurun sebesar 0.066499 ton. Dengan perubahan pola konsumsi atau pengganti dari bahan pangan dari beras ke gandum, roti, jagung, ubi-ubian, dan juga makanan protein sebagainya pengganti dari beras itu sendiri.

Variabel nilai tukar memiliki hubungan negatif terhadap impor beras di Indonesia sebesar -545.2311 artinya jika variabel nilai tukar mengalami peningkatan 1 Rupiah maka impor beras di Indonesia akan mengalami penurunan sebesar 545.2311 ton.

Variabel inflasi memiliki hubungan negatif terhadap impor beras di Indonesia sebesar -5374.586 artinya jika variabel inflasi mengalami peningkatan 1 persen maka impor beras di Indonesia akan mengalami penurunan sebesar 5374.586 ton.

\section{KESIMPULAN DAN SARAN}

\section{Kesimpulan}

Perkembangan impor beras selama tahun 1998-2018 mengalami fluktuasi setiap tahunnya dan cenderung terjadi fluktuasi impor beras di Indonesia, PDB berfluktuasi dan cendrung meningkat, jumlah penduduk mengalami peningkatan setiap tahunnya, nilai tukar mengalami fluktuasi dan cendurng mengalami peningkatan setiap tahunnya sedangkan inflasi cendrung mengalami penurunan setiap tahunnya.

Berdasarkan hasil regresi variabel nilai tukar, jumlah penduduk dan produk domestik bruto berpengaruh signifikan terhadap impor beras di Indonesia. sedangkan variabel inflasi tidak berpengaruh signifikan terhadap impor beras di Indonesia.

\section{Saran}

Hasil penelitian menunjukan bahwa PDB yang cenderung berfluktuasi setiap tahunnya, oleh karena itu kita selaku para ekonomi dan pemerintah harus menjaga PDB negara dengan cara memberikan insentif kepada para petani terkhususnya petani padi dengan melakukan penyuluhan teknologi terkini untuk penanaman padi agar bisa menaikan motivasi petani untuk tetap mau menanam padi, maka dari itu jumlah impor beras akan dapat berkurang dan PDB Indonesia akan mengalami peningkatan. Maka hal ini dapat mendorong apresiasi nilai tukar rupiah.

Pemerintah harus menjaga kestabilan impor beras dengan semua kebijakan yang telah dibuat pemerintah, menekan laju pertumbuhan penduduk agar dapat menghasilkan produksi beras yang cukup untuk memenuhi kebutuhan penduduknya dengan menimalisir impor. Hal ini juga berguna untuk mengatasi depresiasi nilai tukar.

\section{DAFTAR PUSTAKA}

Armaini. (2016). Pengaruh produksi beras, harga beras dalam negeri, dan produk domestik bruto terhadap impor beras Indonesia. Jurnal Ilmiah Mahasiswa Unsyiah.1(2), 455-466

Ghozali, Imam. (2011). Aplikasi Analisis Multivariate Dengan Program SPSS. Badan Penerbit Universitas Diponegoro: Semarang

Gujarati, Damodar. (2013). Ekonometri Dasar. Erlangga: Jakarta

Gujarati, Damodar. (2015). Ekonometri Dasar. Erlangga: Jakarta

Haryadi. (2012). Ekonomi Internasional: Teori dan Aplikasi. Biografika: Bogor.

De,Selien, S; \& Gert Peersman. (2012). The U.S. Dollar exchange rate and the demand for oil. Journal Economic Research Foundation Flanders.36(3), 263-285 
Tandjung, Marolop. (2011). Aspek dan Prosedur Ekspor-Impor. Salemba Empat: Jakarta.

Widarjono. (2013). Ekonometrika Pengantar Dan Aplikasinya. Ekonosia. Jakarta.

Widarjono, Agus. (2017). Ekonometrika Pengantar dan Aplikasi Disertai Panduan Eviews. UPP STIM YKPN: Yogyakarta

Hasyim, A. I. (2016). Ekonomi Makro. Edisi Pertama. PT Fajar Interpratama Mandiri: Jakarta. 